\title{
EXAMINATION OF THE ZINC CONTENT OF THE SOUTHERN GREAT PLAIN AREAS IN TERMS OF NUTRIENT SUPPLY
}

\author{
Judit Petö ${ }^{1^{*}}$, Attila Hüvely ${ }^{1}$, András Palkovics ${ }^{2}$ \\ ${ }^{1}$ Department of Agricultural Science, Faculty of Horticulture and Rural Development, John von Neumann \\ University, Kecskemét, Hungary \\ ${ }^{2}$ Department of Agricultural Economics and Rural Development, Faculty of Horticulture and Rural \\ Development, John von Neumann University, Kecskemét, Hungary \\ https://doi.org/10.47833/2020.2.AGR.027
}

\author{
Keywords: \\ Soil zinc content \\ Great Plain \\ Nutrient supply \\ Horticulture \\ Functional food \\ Article history: \\ Received 4 May 2020 \\ Revised 10 May 2020 \\ Accepted 20 May 2020
}

\begin{abstract}
Among microelements, low level of zinc seems to be the most common property in Hungarian soils. Horticultural cultivation requires a balanced supply of nutrients. Southern part of the Great plain contributes significantly to the supply of the fruit and vegetable to the population, so it is important to follow the soil properties, including measurement of those elements which have special effects on plant growing and human health. In our present investigation we continued the analysis of soils, via determination of the average level and distribution of available zinc content and followed the occurrence of the low and high zinc levels in the surrounding soils. Based on our results we suggest supplementing zinc microelement in plant growing in our region, to get healthy functional products and foods.
\end{abstract}

\section{Introduction}

Zinc deficiency is the most widespread micronutrient deficiency problem in the plants. Zinc is essential for both plants and the animal and human body, as it is a structural component in many enzymes and regulatory factors in many biochemical processes. This is true despite the fact that zinc is not a valence changing element, and when it is incorporated into enzymes, not the promotion of certain redox processes is in the background of the physiological phenomena [10]. Zinc ions exist primarily in complexes, mainly formed with proteins and some nucleic acids.

The proportion of zinc-deficient areas is significant worldwide. According to the scientific literature data, the most affected areas are Central America, Central and South Africa and Southern Asia in the world [1]. In this aspect, Hungary is not in the most endangered countries.

Probably about one-third of the human population suffers from not suitable zinc intake in the world [1]. Increased rates of some diseases (e.g. prostate cancer) were associated with reduced soil zinc concentrations and elevated groundwater use [17]. Zinc plays a key role in growth and development, and the functioning of the immune system [3].

The main soil factors which affect the availability of zinc for plants are low total zinc content in the soil high $\mathrm{pH}$, high calcium carbonate and organic matter contents [15]. Saline soils with high concentrations of $\mathrm{Na}, \mathrm{Ca}, \mathrm{Mg}$, phosphate and bicarbonate are also often show zinc deficiency [2]. However, in very acid soils, soluble concentration of zinc may be significantly higher, indicating that soil $\mathrm{pH}$ is strongly and inversely linked to zinc content [6]. Soil concentration may be affected by

\footnotetext{
* Corresponding author. Tel.: +36 76517661

E-mail address: peto.judit@kvk.uni-neumann.hu
} 
other ligands in the soil, forming stabile complexes; microbial activity and the presence of other micro- macro- and trace elements, as well.

Hungarian natural, uncontaminated soils contain about $10-300 \mathrm{mg} / \mathrm{kg}$ zinc $(50 \mathrm{mg} / \mathrm{kg}$ in the average), but in some industrial area near to zinc smelters it increased up to $1000 \mathrm{mg} / \mathrm{kg}$ [14].

Among plants, maize, rice, bean, grape and fruit trees are the most sensitive for Zn deficiency. Zinc fertilizers, in various form, can be used in the prevention of Zn deficiency. Zinc deficiency symptoms are the following in plants: chlorotic and necrotic leaf tips, interveinal chlorosis in new leaves, retarded growth of entire plant, and injured roots resemble barbed wire [6]. However, apart from crops showing clear deficiency symptoms, in most cases, disappointing yield was later proved to be the result of hidden $\mathrm{Zn}$ deficiency in many areas [21].

Zinc toxicity is rare, but excess use of zinc fertilizers may lead to high zinc content in plants.

Scientific team of our institute make nutrient replenishment experiments for decades, our main results have been reported in a lot of publications. Performing of exact tests are supported via operation of certified Soil and Plant Testing Laboratory of the faculty. Our laboratory is connected to thousands of farmers, and makes tests continuously. Former studies showed that soils in our region are slightly calcareous sand with a low or medium humus content and slightly alkaline in usual [11, 12].

Formerly EU grants for farmers supported total micro- and toxic element analysis in the soil. Nowadays EDTA soluble $\mathrm{Cu}, \mathrm{Zn}$ and $\mathrm{Mn}$ tests are supported. In our study we investigated the level and distribution of zinc content in a large number of soil samples derived from the southern part of the Great Plain, and drew conclusions about zinc supply and its possible physiological consequences.

\section{Materials and methods}

Soil samples, which have been taken and brought into our accredited Soil and Plant Testing Laboratory at the Faculty of Horticulture and Rural Development, John von Neumann University, were processed in our present investigation. The number of samples was highly significant: it was 5090. Most of the soil samples derived from the southern part of the Great Plain, mainly from vineyards and orchards, and in a small extent (about 15\%) from fields. The depth of sampling was $0-30 \mathrm{~cm}$, and in the case of plantations $30-60 \mathrm{~cm}$ as well. The results of samples arriving in 2016, were compared to the results of samples tested in 2008-2009 $(n=752)$, in the similar way.

Soil tests were made by standard methods. Air dry and homogenized soil samples were extracted with $0.05 \mathrm{~mol} / \mathrm{dm} 3$ EDTA solutions, in the presence of $0.1 \mathrm{~mol} / \mathrm{dm} 3 \mathrm{KCl}$. Filtered soil solutions were measured for soluble $\mathrm{Zn}$ level by ICP-OES spectrometry (Horiba). Total $\mathrm{Zn}$ level in soil was also measured by ICP-OES, after $\mathrm{HNO}_{3} / \mathrm{H}_{2} \mathrm{O}_{2}$ microwave digestion in 2008-2009. Number of soil samples was 655.

Results were expressed in $\mathrm{mg} / \mathrm{kg}$ air dry matter. Distribution of soluble $\mathrm{Zn}$ levels in 2016 was also estimated. The frequency of different ranges was calculated in percentage occurrence, as well.

\section{Results}

Most of the samples arrived at our laboratory derived from the Southern Great Plain region of the country. In 2016 , more than 5,000 soil samples we processed in our lab. For estimating the level of the essential zinc micronutrient in soil we can choose more techniques. Hungarian soil test standard uses EDTA extraction solution to estimate the amount of zinc that can be easily taken up by plants. The other opportunity is to determine whole amount of the nutrient after sample exploration by total destruction. Of course, the latter concentration is much larger in usual.

Average level of EDTA soluble zinc and standard deviation in the samples were estimated (Table 1.) Data shows that zinc concentration were in the lower range. Standard deviation of samples was significant. 
Table 1. Average zinc levels in the soil samples in 2016

\begin{tabular}{|r|c|}
\hline & Zn \\
\hline No. of samples & 5090 \\
Average & $2.60 \mathrm{mg} / \mathrm{kg}$ \\
SD & $3.90 \mathrm{mg} / \mathrm{kg}$ \\
\hline
\end{tabular}

$29 \%$ of the samples had Zn concentration lower than $1 \mathrm{mg} / \mathrm{kg}$. In $61 \%$ of the samples, $\mathrm{Zn}$ level was lower than $2 \mathrm{mg} / \mathrm{kg}$, and in $88 \%$ it was lower than $5 \mathrm{mg} / \mathrm{kg}$. Only $0.49 \%$ of the samples had higher $\mathrm{Zn}$ level than $20 \mathrm{mg} / \mathrm{kg} \mathrm{Zn}$. The maximum concentration in the observed sample was 71 $\mathrm{mg} / \mathrm{kg}$, in one case.

Distribution of EDTA soluble Zn level in the soil samples is shown in Figure 1. Zinc showed a lognormal distribution.

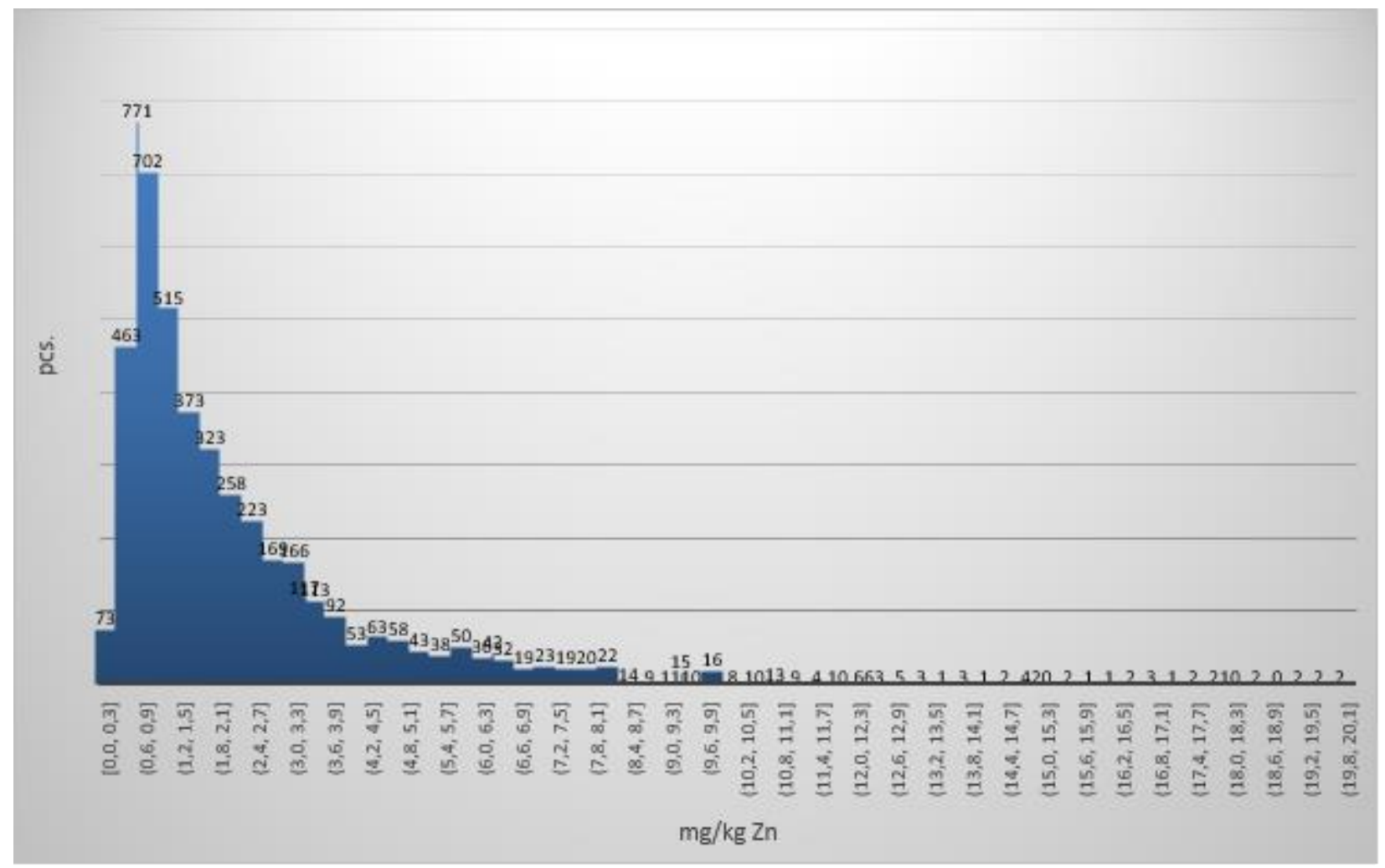

Figure 1. Distribution of EDTA soluble zinc level in the soil samples

At the beginning of the first support period of the EU agri-environmental program in Hungary, testing of the concentration of total microelements and some toxic elements in the soil was obligatory. This time, in 2008-2009, our lab made total element analysis as well. As shown in Table 2., average level in the samples EDTA soluble $\mathrm{Zn}$ content was in the same range than in 2016. Standard deviation of samples and the distribution were similar, as well.

Table 2. EDTA soluble and total zinc concentration in our soils (2008-2009)

\begin{tabular}{|c|cc|}
\hline & $\begin{array}{c}\mathrm{Zn} \\
(\mathrm{EDTA})\end{array}$ & $\begin{array}{c}\mathrm{Zn} \\
\left(\mathrm{HNO}_{3} / \mathrm{H}_{2} \mathrm{O}_{2}\right)\end{array}$ \\
\cline { 2 - 3 } & $\mathrm{mg} / \mathrm{kg}$ & $\mathrm{mg} / \mathrm{kg}$ \\
\hline
\end{tabular}




\begin{tabular}{|r|cc|}
\hline No. of samples & 752 & 655 \\
Average & 2.93 & 28.1 \\
SD & 3.08 & 15.4 \\
\hline
\end{tabular}

Data in Table 2. show that total $\mathrm{Zn}$ level, determined after total digestion of the samples, was about an order of magnitude larger than that of determined by mild EDTA extraction.

On the other hand, we can state that the concentrations in 2008-2009 were in the same concentration range than in 2016. Zinc levels were low in usual in 2008-9 and 2016 as well, so zinc deficiency seems to be a common feature in our region.

\section{Discussion}

Zinc deficiency became evident in large part of the soils in the world, and according to some paper, zinc deficiency is the most ubiquitous micronutrient deficiency problem in the world crops [1]. In our investigation we tested more than five thousand samples, and observed low zinc level in our region. Our previous studies highlighted that these soils are slightly alkaline and have significant calcium carbonate content [12]. These factors probably contribute to the decrease in zinc level taken up by plants [19, 20]. Our sandy textured soils had low humus content in usual [11]. Organic colloids have large specific surfaces and ion exchange capacity, so significantly affect the fertility and nutrient supply of soils in general $[4,5]$.

Average $\mathrm{Zn}$ concentrations did not change regarding 2008-9 and 2016. The observed distribution of $Z n$ levels was in accordance with studies of McLaren et. al [8].

EDTA solvent extraction of soil samples, for estimating micronutrient uptake, was introduced in the sixties [16]. According to the scientific results, EDTA is able to clean the soil from heavy metals, making the easily absorbed microelements soluble creating chelate compounds. Analytical preparation works in a similar way [8].

The uptake of $\mathrm{Zn}$ by plants is approx. one-tenth of all $\mathrm{Zn}$ content, according to our data. Our results are in accordance with that of Szabó et al, who say that sandy soils contain about $30 \mathrm{mg} / \mathrm{kg}$ zinc in Hungary [13]. EDTA soluble zinc proves to be a much more informative data, as it shows the nutrient amount available for plants, i.e., how much the plants are able to absorb from the stock. Good correlation between EDTA-extractable copper and plant uptake has been reported [16].

The vast majority of samples derived from vineyards and orchards in the southern part of Hungarian Great Plain. It is well known that grape and fruit trees are among the most sensitive plants for $\mathrm{Zn}$ deficiency, so we have to make special attention for the supply of this element during plant growing.

Controlled use of organic fertilization, manure use and/or recycling of the organic matter is extremely important in sandy soils to improve soil structure and balance nutrient levels in the soil. Degradation of organic matter in soil results nutrient source for cultivated plants [5, 7, 9]. However, high humus content and strong binding to colloids may decrease the sufficient nutrient uptake.

Further studies are needed

- to compare zinc and other micronutrient levels as well,

- $\quad$ to expand the scope of investigations for other years and to make subgroups with sampling depth and area location,

- to make comparative study of EDTA soluble and $\mathrm{HNO}_{3} / \mathrm{H}_{2} \mathrm{O}_{2}$ zinc levels, though latter tests are much more expensive,

- to compare soil test and plant analysis results,

- to make tests on the effect of foliar fertilization in different growth phases.

- to examine the correlation between $\mathrm{Zn}$ and soil texture whether it is a general deficiency problem in the area or it is problem only on sandy areas. 


\section{Conclusion}

Our region is the centre of horticultural activities of the country and so it is essential and important to follow soil properties, including measurement of those elements which have special effects on plant growing and human health. On the base of processing many thousands of soil samples, we were able to record the distribution curve of this important micro element, and we found that zinc level in soils of our region - except a few cases - is in the lower range. Easily taken up zinc concentration was under $3 \mathrm{mg} / \mathrm{kg}$ in the average. This fact shows that calcareous sandy soils with a slightly alkaline $\mathrm{pH}$ are often may be deficient in zinc level in our region. It may be worthwhile to increase zinc content in the soil and plants in different ways, thus producing even functional foods for the health of the population.

\section{Acknowledgment}

Authors wish to thank for the support of the research carried out in the framework of the EFOP3.6.2-16-2017-00012 „Developing a functional, healthy and safe food product chain model from field to table in a thematic research network". The project is funded by the Hungarian State and the European Union, co-financed by the European Social Fund, and is part of the Széchenyi 2020 program.

\section{References}

[1] Alloway, B. J. (2009). Soil factors associated with zinc deficiency in crops and humans. Environmental Geochemistry and Health, 31(5), pp. 537-548. DOI 10.1007/s10653-009-9255-4

[2] Hajiboland, R., Yang, X. E., Ro"mheld, V., \& Neuman, G. (2005). Effect of bicarbonate on elongation and distribution of organic acids in root and root zone of Zn-efficient and Zn-inefficient rice (Oryza sativa L.) genotypes. Environmental and Experimental Botany, 54(2), pp. 163-173.,DOI 10.1016/j.envexpbot.2004.07.001

[3] Hotz, C., \& Brown, K. H. (eds.). (2004). Assessment of the risk of zinc deficiency in populations and options for its control.Food and Nutrition Bulletin, 25 (Supplement 2), S91-S204.p.

[4] Jiménez Becker S, Ebrahimzadeh A., Plaza Herrada BM, Lao M.T. (2010): Characterization of compost based on crop residues: changes in some chemical and physical properties of the soil after applying the compost as organic amendment. Commun. Soil Sci. Plant Anal. 41. pp. 696-708. DOl10.1080/00103620903563931

[5] Johnston, A. E. (1986). Soil organic matter, effects on soils and crops. Soil use and management, 2(3), pp. 97105. DOl.org/10.1111/j.1475-2743.1986.tb00690.x

[6] Kabata-Pendias, A. (2001). Trace elements in soils and plants (3rd ed.). Boca Raton: CRC Press. 403. p.

[7] Kádár, I. (2015): Összefüggések a talaj termékenysége és tápanyagellátottsága között. MTA Talajtani és Agrokémiai Kutatóintézet (MTA ATK TAKI), 389. p.

[8] McLaren, R. G., Swift, R. S., \& Quin, B. F. (1984). EDTA-extractable copper, zinc, and manganese in soils of the Canterbury Plains. New Zealand Journal of Agricultural Research, 27(2), pp. $207-217$. DOI.org/10.1080/00288233.1984.10430423

[9] Mugnai S, Mais E, Azzarello E, Mancuso S. (2012) Influence of long-term application of green waste compost on soil characteristics and growth, yield and quality of grape (Vitis vinifera L.). Compost Sci Utiliz. 20: pp. 29-33. DOI10.1080/1065657X.2012.10737019

[10] Pais I. (1999). A mikroelemek jelentősége az életben. Mezőgazda Kiadó, Bp., 101. p.

[11] Pető J., Hüvely A., Vojnich V. (2017) New vine and fruit plantations in the southeastern part of Hungary as a way for rural development. Lucrari Stiintifice Management Agricol 19:(2) pp. 133-136.

[12] Petö J., Hüvely A., Palkovics A., Vojnich V. J., (2018): Investigation of some soil physical parameters of the new plantations in the south-eastern part of Hungary Proccedings of the $9^{\text {th }}$ International of Scientific and Expert Conference TEAM 2018., pp. 287-291.

[13] Szabó S. A., Regiusné Mőcsényi Á., Győri D., Szentmihályi S. (1987): Mikroelemek a mezőgazdaságban. Mezőgazdasági, Bp., 235. p.

[14] Takács S. (2001): A nyomelemek nyomában, Medicina, Bp., 265. p.

[15] Trehan, S. P., \& Sekhon, G. S. (1977). Effect of clay, organic matter and CaCO3 content on zinc adsorption by soils. Plant and Soil, 46(2), pp. 329-336.

[16] Ure, A. M., \& Berrow, M. L. (1970). Analysis of EDTA extracts of soils for copper, zinc and manganese by atomic absorption spectrophotometry with a mechanically separated flame. Analytica Chimica Acta, 52(2), pp. 247-257., DOI.org/10.1016/S0003-2670(01)80955-7 
[17] Wagner, S. E., Burch, J. B., Hussey, J., Temples, T., Bolick-Aldrich, S., Mosley-Broughton, C., Hebert, J. R. (2009). Soil zinc content, groundwater usage, and prostate cancer incidence in South Carolina. Cancer Causes \& Control, 20(3), 345. p., DOI.org/10.1007/s10552-008-9248-0.

[18] Wu, L. H., Luo, Y. M., Christie, P., \& Wong, M. H. (2003). Effects of EDTA and low molecular weight organic acids on soil solution properties of a heavy metal polluted soil. Chemosphere, 50(6), pp. 819-822., DOl.org/10.1016/S0045-6535(02)00225-4

[19] Yoshida, S., \& Tanaka, A. (1969). Zinc deficiency of the rice plant in calcareous soils. Soil Science and Plant Nutrition, 15(2), pp. 75-80.

[20] Zhao, A. Q., Tian, X. H., Cao, Y. X., Lu, X. C., \& Liu, T. (2014). Comparison of soil and foliar zinc application for enhancing grain zinc content of wheat when grown on potentially zinc-deficient calcareous soils. Journal of the Science of Food and Agriculture, 94(10), pp. 2016-2022. DOl.org/10.1002/jsfa.6518

[21] Zou, C., Gao, X., Shi, R., Fan, X., \& Zhang, F. (2008). Micronutrient deficiencies in crop production in China. In B. J. Alloway (Ed.), Micronutrient deficiencies in global crop production, Dordrecht: Springer. pp. 127-148. DOI.org/10.1007/978-1-4020-6860-7_5 